\title{
Evaluation of Antioxidant and in vitro Cytotoxic Activity of Triphala on HT29 and HepG2 ${ }^{\dagger}$
}

\author{
Nawin Paul Alexander 1,*, Norliza Shah Jehan Muttiah 1, Kokila Thiagarajah 1, Dhanendiren \\ Narayanasamy 1 \\ 1 Department of Biological Science, Faculty of Science, Tunku Abdul Rahman University, Jalan Universiti Bandar Barat, \\ 31900, Kampar, Perak \\ * Correspondence: norliza@ utar.edu.my; \\ $\uparrow$ Presented at International e-Conference on Bioengineering for Health and Environment (ICBHE 2020)
}

Received: 5.07.2020; Revised: 10.07.2020; Accepted: 12.07.2020; Published: 15.07.2020

\begin{abstract}
An extract of Triphala (TPL), an Indian Ayurvedic formulation with known anti-cancer properties, has been investigated on two human breast cancer cell lines. TPL is consists of dried fruits of three kinds of dried fruits, Phyllanthus emblica Linn, Terminalia chebula Retz. and Terminalia bellerica Gaertn. in equal proportions. The present research was conducted to investigate the antioxidant and in vitro cytotoxic activity of TPL on Human Colorectal Adenocarcinoma Cell Line (HT 29)and hepatocellular liver carcinoma (Hep G2). The methanol extracts of TPL showed significant antioxidant property via DPPH Free Radical Scavenging Assay and Iron Chelating Assay, of which methanol extract demonstrated the highest activity with an $\mathrm{EC}_{50}$ value of $3.052 \mu \mathrm{g} / \mathrm{ml}$ and $10.55 \mu \mathrm{g} / \mathrm{ml}$ respectively. Folin-Ciocalteu Reagent Test and Aluminium Chloride Colourimetric Method also revealed the superiority of methanol in extracting phenolic compounds $(49.35 \mu \mathrm{g}$ GAE/mg) and flavonoids $(99.47 \mu \mathrm{g} \mathrm{QE} / \mathrm{mg})$. The cytotoxic property of the extracts was tested on HT 29 and Hep G2 via 3-(4, 5-dimethylthiazol-2-yl)-2, 5-diphenyltetrazolium bromide (MTT) Assay. Methanol showed good cytotoxicity against HT 29 and Hep G2 cells, having an $\mathrm{IC}_{50}$ value of $101.87 \mu \mathrm{g} / \mathrm{ml}, 86.21 \mu \mathrm{g} / \mathrm{ml}$ , $55.48 \mu \mathrm{g} / \mathrm{ml}$ and $110.31 \mu \mathrm{g} / \mathrm{ml}, 90.71 \mu \mathrm{g} / \mathrm{ml}, 60.21 \mu \mathrm{g} / \mathrm{ml}$ at 24,48 and 72 hours of incubation respectively.
\end{abstract}

Keywords: Antioxidant activity; Cytotoxicity; Cancer cells.

(C) 2020 by the authors. This article is an open-access article distributed under the terms and conditions of the Creative Commons Attribution (CC BY) license (https://creativecommons.org/licenses/by/4.0/).

\section{Funding}

This research received no external funding.

\section{Acknowledgments}

This study was supported by UTAR.

\section{Conflicts of Interest}

The authors declare no conflict of interest. 